\title{
EFFICIENT MANAGEMENT AS OPTIMIZATION OF THE ORGANIZATION
}

\author{
Venelin Tarziev $^{1 *}$, Marin Georgiev ${ }^{2}$ \\ ${ }^{1}$ Corresponding Member of the Russian Academy of Natural History, Moscow, Russia, Prof. \\ D.Sc.(Ec.), D.Sc. (National Security), Ph.D., National Military University, Veliko Tarnovo, Bulgaria; \\ University of Rousse, Rousse, Bulgaria, email: terziev@skmat.com; \\ ${ }^{2}$ Ph.D. student, National Military University, Veliko Tarnovo, Bulgaria, email: clementon@abv.bg.
}

\begin{abstract}
The current scientific research is studies an administrative structure in order to optimize the activities and the overall management. It aims at establishing duplicate functions in the organization under study. The main tasks in the analysis are related to the display of the basic findings and conclusions for the strongest sides and the fields for improvement regarding the relevance, the effectiveness and the efficiency on administration of the Commission on Protection against Discrimination. The following areas are thoroughly and critically analyzed: relevance of the functions and efficiency of the activity. As a result of the study a Strategy for Organizational Development and a Training Plan have been drafted.
\end{abstract}

Keywords: organizational development; professional training; management.

\section{SECTION}

The current report presents the results of the functional analysis of the current situation of the Commission for Protection against Discrimination (CPD) of the Republic of Bulgaria

The purpose of the functional analysis is based on a study and assessment of the relevance of the functions, the effectiveness and the efficiency of the Commission to highlight the main findings on the strengths and the areas for improvement.

The tasks that are formulated relate to the achievement of the main purpose of the analysis and include analysis of the following areas:

- Relevance of the functions in the CPD;

- Effectiveness of the CPD activity;

- Efficiency of the CPD activity.

This functional analysis covers the CPD without analyzing the functions of other authorities with powers in 
the field of protection against discrimination and equality.

The following limitations have been taken into account in the process of the drafting of the analysis:

Analysis of the effectiveness

- The fact that the CPD does not have a defined vision for development and there are no documents defining the strategic and annual objectives of the institution and of the respective structural units is considered as a limitation of the analysis.

- In relation to the above, the CPD does not have defined indicators for measuring the implementation of strategic, annual and operational objectives.

- In the framework of the administration there are no procedures for strategic and annual planning, performance monitoring, preparation of the annual report of the activity.

\section{Efficiency analysis}

- The Commission does not have an information system for reporting the results of the activity in a way that allows systematic and reliable aggregation of information on given indicators. The main results of the activity are based on the Commission's Annual Reports.

- For the analysis is used the provided information on the staff remuneration costs at the organizational level as well as the wages of the regional representatives.

- CPD does not apply program budgeting but only develops budget by economic elements. Therefore, financial-accounting information, it is not possible to value inputs in order to achieve basic performance of activity of the administration by units/function administration, on the basis of which to be calculated the corresponding degree of efficiency. The approach used is to calculate the efficiency at the organizational level by using the information received on staff remuneration and effective work time.

- At the time of the conducting the present analysis, an audit by the National Audit Office is being carried out within the administration, so the report on the auditing and certification of the AFO of the CPD for 2014 is still not validated and published. For analyzing the implementation of the 2014 budget has been used the version of the non-certified financial report provided by the CPD.

- No information on the number of days worked by each of the regional representatives per year has been reported, as the software used by the CPD does not allow the generation of such a report.

The functional analysis was carried out in 2015.A Unified methodology for conducting a functional analysis in the state administration, approved by the Council of Ministers and published on the Public Consultation Portal at the Council of Ministers is being applied. In addition, the LEAN methodology is being applied.

The methods used to perform analysis of the current status include:

- Collecting, researching and analyzing normative acts, strategic and internal documents in order to establish the powers of the authority, the functions of the administration, the objectives set, the achieved results and the resources that have been used.

- poll surveys through preliminary developed questionnaires for managers and staff. The questionnaires were presented to officials and managers from the administration through a specially used internet-based software product. As a result, 44 responses were received, representing $58 \%$ of the total number of the administration;

- conducting of interviews with managers and employees of the CPD in the period $29-30$ April 2015. The interviews were structured with a focus on collecting additional information on issues related to the activity of relevant units - relevance;

- of the functions, the setting of objectives, performance reporting, the resource security, etc .;

- the holding of a meeting with the working group of experts, designated by the CPD on 15 May 2015;

- observations and expert evaluation of the results of the documentary analysis, the survey researches, the interviews and the focus groups by an expert team.

Relevance analysis

Objectives of the Relevance Analysis

The objectives of the analysis of relevance, according to the Uniform Methodology for conducting functional analysis in the state administration, include: 
- identifying the policy areas for which the authority is responsible;

- identifying, grouping and analyzing the powers of the authority;

- identification and grouping of the functions of the structural units in the administration;

- an analysis of the relevance of the functions of the directorates and departments according to the policy areas for which the authority is responsible and its powers, the establishment of atypical functions that can be deduced from the administration;

- analysis of the vertical and horizontal positioning of the functions of the internal units in order to observe the requirements of the normative acts, the presence of completely or partially duplicate functions, the existence of internal units that can be closed or restructured.

Analysis of the current state

Identification of the policy areas for which the authority is responsible

On the basis of the legislation providing for the powers of the CPD as an independent state authority, the following two main policy areas can be identified:

- Policy Area 1: Protection against discrimination and ensuring of equality;

- Policy Area 2: Prevention of Discrimination;

These policy areas cover all the special powers of the Commission under the legislative framework, which are implemented through three types of functions:

- Preventive function;

- Protective function;

- Control function.

Identifying the powers of the authority specified in the legislation

The assignment of powers to the authority is the key initial moment in the process of organizational, functional and administrative structuring of the particular administration, as the main purpose of such structuring is to support the realization of these powers.

Each authority has two main categories of powers:

- Powers of the Head of the Administrative Structure (General Powers);

- Powers which are related to the special competence of the authority (Special Powers).

In this regard, the present report examines the following powers of the CPD, arising from the Protection against Discrimination Act (PaDA) and the Rules of the Structure and Activity of the CPD (RSACPD):

- powers of the CPD chair, arising from his position as head of the administrative structure;

- powers of the Commission and its members, related to its special competence as an independent state body with jurisdictional powers.

The Commission for Protection against Discrimination is a legal entity on budget support - a first-level budget spender. The Commission has its headquarters in Sofia and has its own regional representatives, and the conditions and order for the determination of the territorial structure of the administration of the authority are governed by the RSACPD.

On the basis of the legislation on the management of the administrative structures and the personnel, the following main areas of competence of the CPD chair can be identified as the head of the administrative structure:

- Human resources management;

- Management of financial resources;

- Property management;

- Management of defense mobilization training;

- Information security;

- Administrative services; 
- Information Systems, Record Keeping;

- Legality of the activity;

- Publicity of the activity and protocol.

As regards of the special powers, CPD is an independent, specialized state body for preventing discrimination, protecting against discrimination and ensuring equality of the opportunities. The Commission exercises control over the implementation and observance of $\mathrm{PaDA}$ or other laws governing equal treatment.

According to Art. 47 (1) to (12) of the PaDA, the Commission carries out its activities by:

find out violations of this and other laws, which regulate the equality of treatment, the offender and the affected person;

- state prevention from and termination of the violation and restoration of the initial situation;

- impose the provided sanctions and enforce administrative compulsory measures;

- issue obligatory prescriptions for compliance with this and other laws, which regulate the equality of treatment;

- appeal against the administrative acts, which are in contravention to this and other laws, which regulate the equal treatment, initiate claims before the court and act as a concerned party in proceedings under this and other laws, which regulate the equal treatment;

- issue proposals and recommendations to the state and local self-government bodies to terminate discrimination practices and to revoke their acts, which have been issued in contravention to this and other laws, which regulate the equal treatment;

- maintain a public register of the adopted and entered in force decisions and obligatory prescriptions;

- issue statements on the conformity of the legal act drafts with the legislation for prevention of discrimination, as well as recommendations for adopting, revoking, amending and supplementing legal acts;

- provide independent assistance to the victims of discrimination in constituting complaints against discrimination;

- conduct independent researches related to discrimination;

- publish independent reports and provide recommendations on all issues related to discrimination;

- carry out other competencies, provided in the Rules of Procedure.

Also, according to art. 40, para 5 of PaDA, CPD shall report annually to the National Assembly on its activities not later than March 31 of the following year, which also includes information about the activities of each of its permanent specialized panels.

The RSACPD complements and specifies the specific competencies of the collective body defined by PaDA. Along with the above powers, the Commission: interacts with other state bodies and institutions, local authorities, as well as non-governmental organizations through opinions or participation in the development of draft regulations, exchange of information and other forms of cooperation;

- monitors the compliance with the PADA and also with its secondary legislation of anti-discrimination provisions and with new legislation in the country;

- monitors and takes measures the Bulgarian anti-discrimination legislation to correspond to the EU legislation and the International law;

- carries out and coordinates international cooperation in the field of anti-discrimination policy of the Republic of Bulgaria with international bodies and organizations, as well with similar foreign institutions;

- gives opinions on draft legislation concerning equal treatment;

- adopts rules for the proceedings before it.

- shall adopt internal rules, instructions and methodological guidelines relating to the operational and control activities of the Commission;

- shall adopt the organizational structure, staff and internal rules for salary;

- shall adopt a draft budget for each year thereafter; 
- shall adopt the annual report on the activities of the Commission.

Grouping of powers of the authority defined in the legislation and the functions of the CPD

In accordance with the Unified Functional Analysis Methodology, in the context of this analysis, the powers of the authority - CPD identified in the laws and in the sub legislative acts are grouped according to the defined two policy areas.

In general, explicit regulation of rights, duties and responsibilities of the CPD is identified in 1 law, 5 sub legislative acts and 1 non-normative act of the Council of Ministers.

Policy area 2 "Prevention of Discrimination" has the most extensive regulation - special powers of the CPD are defined in 1 law, 5 sub- legislative acts and one non-normative act of the Council of Ministers, while within Policy Area 1 "Protection against Discrimination and ensuring equality " there is a regulation in 1 law and 1 sub-legislative acts . However, account should be taken of the fact that within Policy Area 1 PaDA, commits to the CPD to exercise control over the application of other laws governing equal treatment (Article 40 (2) of the PaDA), without explicit listing, which leads to uncertainty about the full scope of the powers within the that competence. It is advisable to carry out a detailed review of the national legislation with a view to identify acts and norms relating to equal treatment as a basis for supplementing and specifying the functions of the CPD in the Rules of the Structure and the Activities.

The aforementioned figures for the number of normative acts refer only to the main normative acts in which the special powers of the authority are outlined.

Other acts where the powers of the collective body or the chair of the Commission are further developed in relation to their technical implementation and are not the subject of this analysis (for example, internal rules of procedure before the CPD).

\section{Number of legislative acts by policy area}

Prevention of discriminationl

Protection against discrimination and ensuring equality

$\begin{array}{llllllllll}0 & 1 & 2 & 3 & 4 & 5 & 6 & 7 & 8\end{array}$

- Laws — Sub-legeslative Acts — Non-normative acts

Source: KPMG Bulgaria

Figure 1. Number of acts by areas of special powers of the CPD (policy areas)

In connection with these circumstances, the purpose of the analysis is to clarify the extent to which the administration assisting the exercising of all the powers of the authority is structured in a way that adequately reflects the "sectoral profile" of the collective body - the CPD.

Classification of powers / functions of the authority on policy areas

In accordance with the Unified Methodology for conducting a functional analysis and for the purpose of eventual finding of competencies, not typical for the CPD as an independent specialized state body, was used Classification of the Functions of Government (COFOG), given by the Organization for Economic Cooperation and Development (OECD) in the following categories:

- Functions of sectoral policy - strategic planning, drafting of legislation, development of minimum standards, standards of analysis and assessment of sectoral policy, forecasting.

- Functions for provision of services - providing of services to internal (other state bodies) or external (business, citizens, media, trade unions) clients;

- Regulatory functions - Within the classification, regulatory functions include functions to verify and monitor compliance with the legal provisions. Similar functions are inherent to central executive authorities, as well as to specialized committees. Regulatory functions may also include issuing of licenses, certificates, issuing of permits, accreditation, inspections, financial audit.

- Functions of coordination, supervision and control - coordination of relations between different authorities monitoring of the activities of accountable (subordinate) structures, supporting these structures for achieving their goals;

Supportive functions - accounting, recordkeeping, human resources management, information systems, public relations, organizational infrastructure, staff training, efficacy analysis and audit management, secretarial services. The overall distribution of the special powers by type of the CPD functions is presented in Figure 2 (Functions of sectoral policy $-44 \%$; Functions for provision of services $-4 \%$; Regulatory functions $-22 \%$; 
Functions of coordination, supervision and control $-15 \%$ and Supportive functions $15 \%$ ).

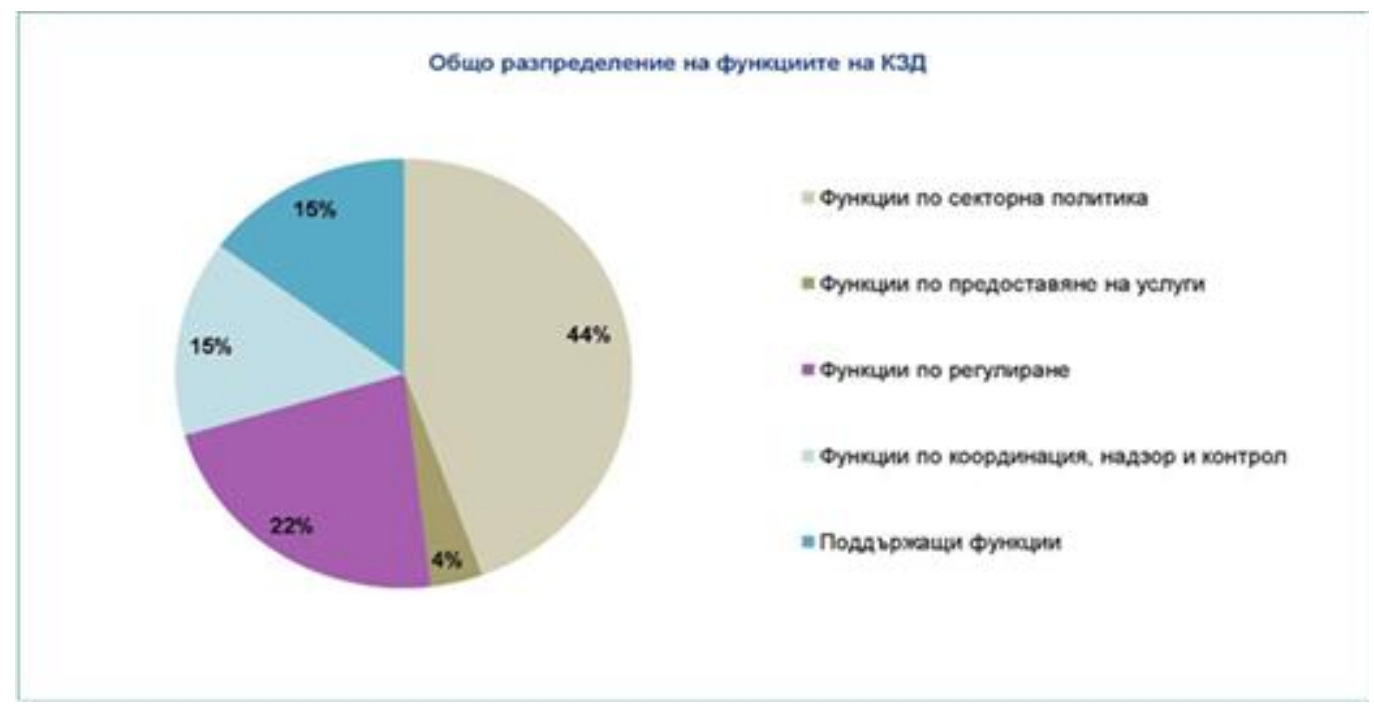

Figure 2. General distribution of the CPD's special competence according to the OECD classification

The largest is the share of sectoral policy functions (12 functions, 44\%), but mainly concentrated in Policy Area 2: Prevention of Discrimination (a total of 11 out of 12 functions of sector policy). Here, it should be noted that the functions that are defined as sectoral policies are categorized to some degree conditionally. In principle, in order to determine whether a body of authority conducts a comprehensive and complete sectoral policy it is necessary to include it legally at all stages of the implementation of the specific policy: the identifying of the problems (the public relations for state regulation); policy formation; developing of toolkits; decision making; execution; analysis and evaluation with a view to decision making for continuation, correction or suspension of the policy. In this sense, the CPD does not have the full set of powers to selfimplement the sectoral policy in the field of prevention and protection against discrimination.

The functions that may be assigned to the sectoral policy category are the following: the functions of a consultative body with regard to the country's prevention policy; the review of legislation on compliance with the anti-discrimination rules; provision of competent opinions and participation in working groups on drafting of legislative acts, participation in advisory councils on social inclusion, ethnic issues, national human rights coordination mechanism, program monitoring committees, co-financed by EU structural and investment funds and others, including the preparation of specialized analyzes and reports on issues related to the prevention and the protection against discrimination.

The second largest group of special powers are the regulatory functions (6 functions, 22\%), which is a consequence of the specific competence of the CPD, related to the control over the compliance with the provisions of $\mathrm{PaDA}$, including establishing and sanctioning of violations, control over the implementation of the decisions, the conciliation agreements and the coercive administrative measures.

Practically, the regulatory functions (verification and monitoring of compliance with legislation) most closely reflect the specificities of the CPD as a specialized independent state authority with jurisdictional powers in the field of protection against discrimination. It should be borne in mind that the percentage ratio which places the regulatory functions in second place does not necessarily reflect the actual functional load of the CPD. Their number, compared to the number of sectoral policy functions is smaller on the basis of simple calculation, as regulatory functions are represented in high-level regulatory acts. The specific activities carried out by the Commission in the anti-discrimination proceedings (for example, admissibility checks, regularity and fitness of the complaints and signals, actions in the inquiry procedure, in the hearing phase and other actions that take place on the basis of procedural rules defined in the law) are not included in the general calculation of regulatory functions, as they can not be defined as functions but as working processes.

The next group of special powers ate the functions fore coordination, control and supervision (4 functions, $15 \%$ ) allocated equally between the two identified policy areas. This group includes specific functions related to the control of the CPD on the activities of other state bodies and municipalities, cooperation with other bodies as well as the coordinating role of the Commission for the implementation of international cooperation in the field of the anti-discrimination policy of the country.

The supportive functions that fall within the group of special powers (outside the typical functions of the 
general administration, such as accounting, record keeping, information systems, etc.) are 4 functions, $15 \%$. Here fall the functions of keeping the public register of the issued and enforced decisions and the binding prescriptions of the Commission, the informing of the public through the media about the current provisions in the field of protection

against discrimination, as well as the functions related to the elaboration of rules of procedure before the CPD and other internal rules, instructions and methodological instructions related to the operational and control activities of the CPD.

Fewer are the service provision functions (1 function, $4 \%$ ), which is related to the provision of independent legal assistance to victims of discrimination in the submission of complaints to the Commission.

Of the examined types of functions, half are assigned by sub-legislative acts (mainly RSACPD). This is due to the perception in the PaDA approach to refer to the RSACPD for additional functions and powers of the CPD.

The distribution of the types of functions by policy area shows that the functions within Policy Area 1: protection against discrimination and ensuring of equality are most varied. In this area of policy, the CPD has functions in the field of sectoral policy, service provision, regulation, coordination, control and supervision and supporting functions. The largest is share of regulatory functions, which are concentrated only in this area.

Policy Area 2: Prevention of Discrimination consists essentially of sectoral policy functions complemented by 2 functions for coordination, control and supervision functions and 1 supporting function within the framework of the special powers of the authority.

The main share of supportive functions is concentrated in Policy Area 1: protection against discrimination and ensuring of equality. It should be noted as a good practice that the total number of supportive functions (not typical of the general administration) is not large, thus preserving the focus of the CPD's work on the core set of specific powers that are entrusted to it.

The drafted categorization of policy areas and typology by function can be used as a basis for possible changes in the organizational structure of the CPD administration.

- Other authorities related to the same/related policy areas

- Bellow are outlined theauthorities and other organizations that have substantial role in the implementation of the two main policy areas of the CPD.

- Ombudsman of the Republic of Bulgaria - the Ombudsman is a body that advocates when acts or omissions affect or violate the rights and freedoms of citizens by the state and the municipal authorities and their administrations as well as by the persons entrusted with the provision of public services In its activity, the Ombudsman adopts and reviews complaints and signals of violations of rights and freedoms by the state and municipal authorities and their administrations, makes proposals and recommendations for the restoration of the violated rights and freedoms to the respective bodies, mediates between administrative bodies and the affected persons and recommends removing of the causes and conditions that create preconditions for violations of rights and freedoms;

- Ministry of Labor and Social Policy - in connection with the implementation of the national policy on equality between men and women, as well as ensuring the equality of people with disabilities;

- Ministry of Education - cooperation on ensuring equal access to education, including support for the development of sectoral strategies related to the integration of representatives of minority groups and disadvantaged people within the education system;

- Ministry of Foreign Affairs - cooperation in the framework of activities of international organizations in which the Republic of Bulgaria is a member state;

- National Council for Cooperation on Ethnic and Integration Issues at the Council of Ministers - CPD assists the National Council in proposing measures for the implementation of the national policy in the field of protection against ethnic discrimination (Article 3, item 9 of the Rules for Organization and Activities of the National Council on Ethnic and Integration Issues);

- Ministry of the Interior - Ministry of Interior assists the CPD in the collection of evidence in the framework of the the proceedings under Section I of the PaDA (Article 57 (4)). $\square$ Ministry of Regional Development and Public Works, "National Construction Control" Directorate and municipalities - in relation to the functions of providing accessible environment for the population and people with disabilities in accordance with the 
provisions of the Spatial Development Act and Ordinance № 4 from 01.07.2009 on the Design, Implementation and Maintenance of Buildings in accordance with the requirements of an accessible environment for the population, including people with disabilities.

It should be noted that the order for organizing and implementing the cooperation and external communication links of the CPD with other authorities is extremely low in the framework of the RSACPD and there is no explicit regulation regarding the specific functions and the responsible units within the administration. Such gaps can lead to gaps and delays in the interaction process, which in turn hinders the implementation of the Commission's statutory powers. In this respect, it is necessary to develop a mechanism, including the areas, the specific functions and the responsible units, which carry out the interactions of the Commission with other authorities.

\section{Evaluation of the quality of external communication and coordination links}

In the framework of the survey carried out, the heads of administrative units of the CPD assess the timeliness and the reliability of the communications and the coordination with the external administrations. A large number of employees (52.5\%) are of the opinion that the timeliness and reliability of the CPD's external communication and coordination links are good, while $15 \%$ indicate that there are omissions, both in terms of reliability and timeliness. $12.5 \%$ of the respondents indicate shortcomings in terms of timeliness and $10 \%$ indicate that the term and the reliability are not at the required level, which creates prerequisites for poor fulfillment of the obligations as good (100\%).

The current scientific research is studies an administrative structure in order to optimize the activities and the overall management. It aims at establishing duplicate functions in the organization under study. The main tasks in the analysis are related to the display of the basic findings and conclusions for the strongest sides and the fields for improvement regarding the relevance, the effectiveness and the efficiency on administration of the Commission on Protection against Discrimination. The following areas are thoroughly and critically analyzed: relevance of the functions and efficiency of the activity. As a result of the study a Strategy for Organizational Development and a Training Plan have been drafted (Terziev, Dzhumalieva, Parvanov, 2017; Zhelezarov, 2009; Zhelezarov, 2008; Zhelezarov, Hristov, 2007a; Zhelezarov, Hristov, 2007a; Zhelezarov, Hristov, 2007b; Zhelezarov, 2006a; Zhelezarov, 2006b; Zhelezarov, 2005a; Zhelezarov, 2005b; Zhelezarov, 2005c; Zhelezarov, 2004; Zhelezarov, Hristov, 2003a; Zhelezarov, 2003b; Nikolov, Nemigenchev, Zhelezarov, 2002; Zhelezarov, 2001a; Zhelezarov, 2001b; Ivanov, Zhelezarov, 1998a; Ivanov, Zhelezarov, 1998b; Ivanov, Zhelezarov,1997).

\section{REFERENCE LIST}

Terziev, V., A. Dzhumalieva, R. Parvanov (2017), Efficient management as optimization of the organization, International Journal Scientific Papers. Vol.20.3. GRAFOPROM - Bitola, IKM - Skopje.

Zhelezarov, I. S. (2009) Otsenyavane na sistemite za upravlenie na kachestvoto na visshite uchilishta. „Kachestvo na vissheto obrazovanie v Balgariya - Problemi i perspektivi 2009“. Ruse. (Железаров, И. C. (2009) Оценяване на системите за управление на качеството на висшите училища. „Качество на висшето образование в България - Проблеми и перспективи 2009“. Русе).

Zhelezarov, I.S. (2008) Metodi za statistichesko upravlenie na protsesite. „UNITEH 2008”. Gabrovo., str. II476 - II479. ISSN 1313-230X. (Железаров, И.С. (2008) Методи за статистическо управление на процесите. „УНИТЕХ 2008”. Габрово., стр. II476 - II479. ISSN 1313-230X).

Zhelezarov, I. S., H. K. Hristov. (2007a) Integrated Management Systems. Radmi 2007. Belgrade, Serbia. ISBN 978-86-83803-22-4.

Zhelezarov, I. S., H. K. Hristov. (2007b) Sistema upravleniya kachestvom v tehnicheskom universitete Gabrovo. „Problemi inzhenerno-pedagogichnoe osviti”. Harkov, str. 69 - 76. (Железаров, И., Ил. Немигенчев, Д. Маркова, К. Киров, (2007) Система управления качеством в техническом университете - Габрово. „Проблеми инженерно-педагогичное освити”. Харков, стр. 69 - 76). 
Zhelezarov, I. (2006a) Izmervane na protsesite i produktite kato faktor za podobryavane na sistemite za upravlenie na kachestvoto. Mashinostroene i elektrotehnika, broy 1/2006. Sofiya, str. 22-25. ISSN 0025-455X. (Железаров, И. (2006) Измерване на процесите и продуктите като фрактор за подобряване на системите за управление на качеството. Машиностроене и електротехника, брой 1/2006. София, стр. 22-25. ISSN 0025-455X).

Zhelezarov, I. (2006b) Normativna baza na universitetska sistema za upravlenie na kachestvoto. Parva natsionalna nauchna konferentsiya s mezhdunarodno uchastie „Kachestvo na vissheto obrazovanie 2006". Ruse, 2006. (Железаров, И. (2006) Нормативна база на университетска система за управление на качеството. Първа национална научна конференция с международно участие „Качество на висшето образование 2006”. Русе, 2006).

Zhelezarov, I. S. (2005a) Analiz na vliyaeshtite faktori na produkt, na bazata na rezultatite ot izmervaniya s malki izvadki. AMTEH 2005. Ruse, str. 603 - 608. ISSN 1311-3321. (Железаров, И. С. (2005) Анализ на влияещите фактори на продукт, на базата на резултатите от измервания с малки извадки. AMTEX 2005. Русе, стр. 603 - 608. ISSN 1311-3321).

Zhelezarov, I. S. (2005b) Analiz na dannite polucheni pri izmervane kachestvoto na obuchenie vav visshite tehnicheski uchilishta. Nauchen simpozium „Metrologiya i metrologichno osiguryavane 2005”. Sozopol, str. 331 - 334. ISBN 954-334-008-0. (Железаров, И. С. (2005) Анализ на данните получени при измерване качеството на обучение във висшите технически училища. Научен симпозиум „Метрология и метрологично осигуряване 2005”. Созопол, стр. 331 - 334. ISBN 954334-008-0).

Zhelezarov, I. (2005c) Metods for data processing from measurement and testing with small sample sizes. Radmi 2005. Vrnjacka banja, Serbia and Montenegro. 2005. p. 562 - 565. ISBN 86-83803-20-1.

Zhelezarov, I. S. (2004) Otnosno kolichestveno otsenyavane kachestvoto na obuchenie v Tehnicheski universitet - Gabrovo. Nauchen simpozium „Metrologiya i metrologichno osiguryavane 2004”. Sozopol, str. 376 - 380. ISBN 954-9725-89-8. (Железаров, И. С. (2004) Относно количествено оценяване качеството на обучение в Технически университет - Габрово. Научен симпозиум „Метрология и метрологично осигуряване 2004". Созопол, стр. 376 - 380. ISBN 954-9725-89-8).

Zhelezarov, I. S., H. K. Hristov (2003a). Quality management System - Faktor for successful accreditation of Higher Technical Institute. Radmi 2003. Herceg Novi, Serbia and Montenegro. p. 1140 - 1145. ISBN 86-83803-06-6.

Zhelezarov, I. S. (2003b) Dokumentirane na informatsiyata na universitetskite sistemi za upravlenie na kachestvoto. Informatsionen byuletin 1. Proekt „Usavarshenstvane universitetskite sistemi za upravlenie na kachestvoto na obuchenieto". Ruse. str. 82 - 110. ISBN 954-712-211-8. (Железаров, И. С. (2003) Документиране на информацията на университетските системи за управление на качеството. Информационен бюлетин 1. Проект „Усъвършенстване университетските системи за управление на качеството на обучението". Русе. стр. 82 - 110. ISBN 954-712-211-8).

Nikolov, I., I. Nemigenchev, I. Zhelezarov. (2002) Ein model des ausbildungs- prozesses an der standards ISO 9000:2000. IWKM 2002/ Bildungsforum. Mittweida. p. 29 - 33. ISSN 1437-7624.

Zhelezarov, I. S. (2001a) Izmervane iziskvaniyata i udovletvorenostta na klienta. AMTEH 2001. Sozopol. Tom 4, str. 99 - 104. ISVN 954-438-306-9. (Железаров, И. С. (2001) Измерване изискванията и удовлетвореността на клиента. АMTEX 2001. Созопол. Том 4, стр. 99 - 104. ISBN 954-438-306-9).

Zhelezarov, I. S. (2001b) Sistema za upravlenie na kachestvoto na TU - Gabrovo. Sbornik dokladi HII nauchno-prakticheska natsionalna konferentsiya s mezhdunarodno uchastie „Kachestvoto za podobar zhivot'2001". Sofiya, str. 76 - 81. (Железаров, И. С. (2001) Система за управление на качеството на ТУ - Габрово. Сборник доклади XII научно-практическа национална конференция с международно участие „Качеството за по-добър живот'2001”. София, стр. 76 - 81).

Ivanov, I. N. i I. S. Zhelezarov. (1998a) Otnosno kachestvoto na uchebniyat protses vav visshite uchebni zavedeniya. Yubileyna nauchna sesiya s mezhdunarodno uchastie - 120 godini ot sazdavaneto na VVOVU „Vasil Levski” . Veliko Tarnovo. (Иванов, И. Н. и И. С. Железаров. (1998) Относно качеството на учебният процес във висшите учебни заведения. Юбилейна научна сесия с международно участие - 120 години от създаването на ВВОВУ „Васил Левски”. Велико Търново).

Ivanov, I. N. i I. S. Zhelezarov. (1998b) Upravlenie na proekta/razrabotkata kato element ot sistemata za upravlenie na kachestvoto na VUZ. Yubileyna nauchna sesiya s mezhdunarodno uchastie -120 
godini ot sazdavaneto na VVOVU „V. Levski” . Veliko Tarnovo. (Иванов, И. Н. и И. С. Железаров. (1998) Управление на проекта/разработката като елемент от системата за управление на качеството на ВУЗ. Юбилейна научна сесия с международно участие - 120 години от създаването на ВВОВУ „В. Левски”. Велико Търново).

Ivanov, I. N. i I. S. Zhelezarov.(1997) Metodichni printsipi pri obuchenieto po upravlenie na kachestvoto v TU - Gabrovo. AMTEH'97. Gabrovo, 1997, Napravlenie 2, str. 256-264. ISSN 954-683-050-h. (Иванов, И. Н. и И. С. Железаров.(1997) Методични принципи при обучението по управление на качеството в ТУ - Габрово. АМТЕХ'97. Габрово, 1997, Направление 2, стр. 256-264. ISSN 954683-050-x). 